Revue

d'ethnoécologie
Revue d'ethnoécologie

6 | 2014

Conservation de la nature : quel rôle pour les sciences sociales?

\title{
The role of ethnoscience in the build-up of ethnoconservation as a new approach to nature conservation in the tropics
}

The case of Brazil

Le rôle de l'ethnoscience dans la mise en place de l'ethnoconservation comme nouvelle approche pour la conservation de la nature dans les tropiques : le cas du Brésil

\section{Antonio Carlos Diegues}

\section{OpenEdition}

\section{Journals}

Electronic version

URL: http://journals.openedition.org/ethnoecologie/1956

DOI: 10.4000/ethnoecologie.1956

ISSN: 2267-2419

Publisher

Laboratoire Eco-anthropologie et Ethnobiologie

\section{Electronic reference}

Antonio Carlos Diegues, «The role of ethnoscience in the build-up of ethnoconservation as a new approach to nature conservation in the tropics », Revue d'ethnoécologie [Online], 6 | 2014, Online since 31 December 2014, connection on 30 April 2019. URL : http://journals.openedition.org/ ethnoecologie/1956; DOI : 10.4000/ethnoecologie.1956

This text was automatically generated on 30 April 2019.

\section{c)}

Revue d'ethnoécologie est mis à disposition selon les termes de la licence Creative Commons Attribution - Pas d'Utilisation Commerciale - Pas de Modification 4.0 International. 


\title{
The role of ethnoscience in the build-up of ethnoconservation as a new approach to nature conservation in the tropics
}

The case of Brazil

\author{
Le rôle de l'ethnoscience dans la mise en place de l'ethnoconservation comme \\ nouvelle approche pour la conservation de la nature dans les tropiques: le cas \\ du Brésil
}

Antonio Carlos Diegues

\section{Introduction}

1 The purpose of this paper is to discuss the role of ethnoscience (ethnobiology and ethnoecology in particular) in building a new approach to nature conservation in the Tropics called ethnoconservation. The starting point is a critique of the classic/hegemonic approach to conservation of protected areas which is far from achieving its main ecological objectives in tropical regions, in addition to creating serious problems for indigenous and traditional peoples. According to this approach, traditional (indigenous) peoples and traditional communities should either be expelled from their territories when these are being transformed into no-take protected areas, or forbidden to maintain their livelihood mainly based on the use of natural resources through small scale agriculture, fishing and forest extractivism.

2 In the hegemonic approach to nature conservation, only natural sciences - especially biology and botany - are used in the planning and management of these no-take protected areas. It is internationally recognized, however, that traditional peoples and communities can play a crucial role in nature conservation through their traditional knowledge on living species and habitats as well as through their socioeconomic and 
symbolic practices. In this connection, ethnoecology is bound to play a crucial role as a bridge between natural and social sciences. Ethnoscience, in addition to social participation, to respect to social rights and livelihood of the traditional peoples and communities, is the cornerstone of new models and approaches to nature conservation and protected areas in the tropics that are defined here as ethno-conservation. Ethnoecology can be defined as « an interdisciplinary approach exploring how nature is seen by human groups, through the screen of beliefs and knowledge and how humans use or manage natural resources » (Toledo $2001: 7$ ).

\section{The conservation approach based on no-take protected areas in the tropics}

The hegemonic preservation approach to conservation based on no-take protected areas has been criticized, especially in Southern Countries, by social movements, socioecological organizations, and by a growing number of biologists and social scientists for the last 20 years at least (Gomez-Pompa \& Kaus 1992; Balée 1993 ; Diegues 1998, 1999 ; Toledo 1992, 2001 ; Mac Chapin 2004 ; Sarkar 1998 ; Bahuchet et al. 2000 ; Chimere-Diaw 2008).

4 The hegemonic approach to conservation is based on: a) the notion of wilderness which appeared mainly in US in the middle of the $19^{\text {th }}$ century, in the set-up of no-take zones from which human beings, including indigenous people, should be expelled (Sarkar 1998; Diegues 1999); b) the naturalist notion that every human being and all societies, regardless of their rationality and social organization, are, per se, a threat for nature - human beings are equivalent threats according to most of the conservationist organizations; c) the importance of natural sciences in the planning and management of these protected areas. In most cases, only natural sciences are used despite the presence of traditional peoples/ communities and their traditional knowledge about the forests and the sea in most of the territories where these conservation areas are established - according to this hegemonic view, conservation is not a social practice but derives from the application of natural sciences; d) the lack of involvement from local social groups.

No-take protected areas, established without consulting with the people living in that territory, are considered by the " preservationists » the only way to protect biodiversity, (in natural sciences terms only). Police force and suppression are often used to « protect biodiversity and top-down approaches hinders any democratic way of managing biodiversity with indigenous people living inside those parks » (Sarkar 1998 ; Dowie 2006).

6 The transfer of the "wilderness model » to Third World Countries has resulted in the « expulsion of indigenous people » from their territories and in serious constraints on the traditional way of living of local populations, violating their land rights and compelling many of them to social marginality (Chapin 2004).

7 As wilderness transforms indigenous peoples' territories into a no place where no social relations may exist, the only sciences considered to be useful are natural sciences. In countries such as Brazil, the expansion of this model was made possible in the 1960s through an alliance of preservationist NGOs, natural scientists and State bureaucracies, particularly during the military regime (1964-1984) when many no-take protected areas were created, mainly in the Amazonian region. 
8 A new wave of no-take conservation areas emerged in Brazil in the 1980s onwards with the arrival of the BINGOs (Big International NGOs') such as World Wildlife Fund (WWF), The Nature Conservancy (TNC) and Conservation International (CI). They came with funds, influence, concepts and strategies to implement protected areas programmes. Some of them, such as TNC, bought land and transformed it into no-take zones, often using local NGOs as intermediaries and creating suspicion among national political forces. It became clear (Guha 1997 ; Sarkar 1998) that wilderness was not an isolated concept, but it came associated with a philosophy (deep ecology) and a natural science model: Conservation Biology.

In the beginning, BINGOs were mainly interested in setting up isolated no-take protected areas, and their science was based on elements of the ecosystem theory and conservation biology (Chimere-Diaw 2008; Sarkar 1998; Guha 1997). Most of the agenda put forward and conducted by the BINGOs consider conservation as a «natural » issue (protection of biodiversity, of endangered species). Discussion on issues such as science and power or power and conservation has been avoided. (Chimere-Diaw 2008). We argue here that the discussion on conservation also has a political aspect, particularly in countries like Brazil where the territory covered by protected areas is larger than many entire European countries.

In the decade of 1990, BINGOs launched the so-called «global» conservation that was based on concepts and strategies of large-scale such as " hot spots ", biological corridors, large-scale landscape, bio-regions (Chimere-Diaw 2008). This large-scale conservation was more in line with the concerns of « global » institutions such as the World Bank, a few big North-American Foundations and Private Corporations that sit in the BINGOs boards (Chapin 2004). The definition of the above mentioned concepts excluded local populations, although the larger the scale the bigger the risk of not seeing local populations living in the forests and coastal areas of the Southern Countries (Chapin 2004 ; Dowie 2006).

11 For example, in February 2006, USAID launched the Amazon Basin Conservation Initiative, comprising countries located in the area. The programme was based on a largescale conservation that would ultimately be implemented by North-American BINGOs. The Brazilian Government rejected this plan on the argument that it was not even consulted (Diegues 2008).

In fact, since the beginning of the 1990s, the BINGOs (especially WWF, CI and TNC) have organized national workshops aiming to define biodiversity conservation priorities (hot spots). Some central concepts, such as biodiversity, were defined differently by natural and social scientists in Brazil. In the process coordinated by BINGOs for defining " hot spots » for biodiversity conservation, only natural variables are considered in spite of the fact that in tropical forests many of these hotspots are inhabited by traditional peoples (and other traditional groups) who have been inhabiting the forest for centuries (Toledo 2001).

13 These historical and cultural relationships and social practices (slash and burn agriculture, traditional management, etc.) have limited impact on tropical forests that some biologists and NGOs continued to refer to "pristine " and wild. These views on pristine ecosystems have been criticized by ecologists such as Gomez-Pompa \& Kaus (1992) and Balée (1993) as well as by social scientists (Sarkar 1998; Toledo 2001). In the rare occasions where a social scientist is invited to define priority conservation areas, 
their role is to enumerate human «threats» on biodiversity, particularly by local dwellers threats (Diegues 2008).

Social Scientists were absent in the debate until mid of the mid-eighties when a new category of protected area - the extractive reserve - was created, as a result of the fight of the rubber-tappers against deforestation, the loss of territory and of access to natural resources. These reserves were supported by strong political movements (such as the National Council of Rubber-Tappers and some eco-socially oriented local and international NGOs) that were able to influence conservation policies in the country. One crucial element in this process is the recognition that forest peoples have an important contribution to make for conservation through their traditional knowledge and management of natural resources. Since then, traditional knowledge and management were offered as an important contribution for the planning and implementation of the sustainable use reserves.

In Brazil, from the 1980s onwards, there was a series of conflicts between the preservationists (government environment officers and NGOs) who controlled the State's environmental bureaucracy on one side, and socio-environmentalists and social movements/social environmentalists on the other. These conflicts arose during the meetings that preceded the National system of Protected Areas (SNUC), eventually approved by Congress in 2000. For the first time, the presence of traditional peoples in no-take protected areas was officially recognized and sustainable use protected areas were included in the document (extractive reserves and sustainable use reserves).

One of the main outcomes was the creation of «new commons " (common property regimes) as the land (and also the sea, in the case of marine areas), although theoretically Stateowned, was given back to the reserve associations as long-term concessions. Many challenges exist for the actual consolidation of these reserves in social, political and environmental sustainability terms. Newly created, they represent an important field of social and environmental experiments of cooperation among social and natural sciences.

\section{Traditional people's rights and Government policies}

17 Since the end of the military regime (1984) and the beginning of a new democratic period, important social movements have arisen in Brazil, among them the Landless People Movement, the Indian organizations, the National Council of Rubber-Tappers, the Artisanal Fishermen organization, the «Quilombola » movement (descendants of African slaves). In December 2006, the Federal Government has created the National Commission for Traditional Peoples, in which Indian and Traditional Communities participate. This commission comprises Indian peoples, Quilombola communities, Amazonian Caboclos, artisanal fishers, Caiçaras fishers, inter alia. In an official document - Policies for the Sustainable Development of Traditional Peoples and Communities - issued in 2007, they are defined as culturally distinct social groups recognizing themselves as such, having their own social organizations, basing their livelihood on the use and management of natural resources.

The main features of traditional peoples are: a) strong economic and symbolic ties with the land and the sea through continuous observation of the natural cycles; b) attachment to continual use and occupancy of a specific group territory which allows a community to reproduce itself through on-going traditions of communal and family land and sea 
tenure; c) vital role of subsistence activities in their economy, and important production; d) individual/family ownership of means of production; e) limited accumulation of capital; f) crucial socio-economic relations that are structured along family, domestic, communal kinship lines; g) the use of relatively simple technology, with limited impact on the environment; $h$ ) positions of marginality from political power bases that tend to be concentrated in urban centres; i) oral traditions responsible for the production and transmission of knowledge, symbols, myths and rituals associated with artisanal fishing, forest harvesting and small-scale agriculture; $\mathrm{j}$ ) social identity is a fundamental issue.

\section{Basic Principles guiding an Ethnoconservative approach}

19 This approach, which is under development in various tropical countries, is based on research, socio-ecological thoughts and social practices on biodiversity and nature conservation that emphasize the need for involvement from traditional peoples, their culture, social organizations, traditional knowledge and management. Ethnoconservation is guided by certain principles:

20 - Nature conservation for traditional peoples is the result of social practices and associated knowledge, management, perceptions and ethics, and not seen as an isolated issue from other aspects of their culture, as it happens in Western industrial/urbanized societies.

21 - Adequate nature conservation has to be based on the recognition of the rights of traditional peoples to live with dignity in their own territories. The notion of territory to which they are attached is fundamental for traditional peoples because that is where their culture, social relations and traditional knowledge are produced there. The 'territory', which a particular society claims as its own, grants to all or to a part of its members stable rights of access, control and use for all or part of the natural resources located there, that they wish or are capable of utilizing (Godelier 1984). This territory furnishes, first of all, the nature of humans as a species, but also the means of subsistence, the means of production and the means of producing material aspects of social relations, such as kinship relations (Godelier 1984). The respect for their livelihood, besides the guarantee of staying in the territory of their ancestors, should include adequate access to health, education, infrastructure and also their decision to change aspects of their culture in contact with other cultures (Bahuchet et al. 2000).

22 - Biological diversity can only be protected when cultural diversity is respected and vice-versa. There is evidence that many isolated forest areas pending transformation in protected areas (particularly national parks) are inhabited by indigenous peoples. This overlapping is not accidental as it has been shown by many researchers (Toledo 2001; Diegues 1999 ; Alcorn 1993 ; Gomez-Pompa \& Kaus 1992). The high biodiversity existing in indigenous territories is the result of traditional knowledge and management practices.

23 - Traditional knowledge and management practices are fundamental for biodiversity conservation. Traditional knowledge may be understood as a distinct cognitive realm: on the one hand consisting of a replicable, orally transmitted set of specialized skills and culturally shared practices and beliefs that have stood the test of time, enabling people to make a living from different environments such as forests, savannahs coastal and marine environments, relying on artisanal techniques. On the other hand, traditional fishing knowledge exists in more encompassing symbolic and conceptual frameworks governing 
social relationships and spiritual connections to the various habitats of their territories. (Diegues \& Cordell 2001).

It can also be defined as a cumulative body of knowledge and beliefs handed down through generations by cultural transmission about the relationship of living beings (including humans) with one another and their environment (Gadgil et al. 1993).

On the basis of this knowledge, traditional peoples and communities take decisions on where, when and how to plant or to fish, through a multi-use strategy that maximizes the variety of goods produced providing the family with basic requirements throughout the year (crops, fish, handicrafts. etc.).

The construction of this body of complex and detailed concepts and symbols is based on a long-term empirical observation and is applied to rather small areas used by local communities and can seldom be replicated elsewhere.

As Ruddle points out (2000: 282):

« Resource use patterns are products not of their physical environment and its resources per se, but of their perceptions or culturally formed images of the environment and its resources. Thus, to properly understand human ecological relationships, an understanding of a society's local knowledge base, and the cognitive system that underlies it, is crucial ».

The social appropriation of the nature implies an extension of social relationships on land and the accumulation of local environmental knowledge. But it also involves the formation and symbolic expression of links with the spiritual world. Conceptions and representations of the natural world and its resources differ greatly between the subsistence and market-oriented societies. Godelier (1984) argues that these two societies have different rationales, and each of them displays a system of social rules consciously elaborated to best attain a set of objectives. According to this anthropologist, each economic and social system creates a specific mode of exploitation of natural resources and of use of the human labour force and, consequently, utilizes specific norms of good and bad use of natural resources.

25 - Biodiversity is also maintained through social values that reveal a particular cosmovision of traditional peoples and communities. According to this cosmovision, nature has a sacred non-market value and land, as well as water and sea are primary sources of their livelihood (Toledo 2001; Berkes 1999). In this connection, their representation and classification of the territories they occupy and the elements (forest, water, natural processes) are the core of their culture and the origin of their identity (Toledo 2001).

According to Godelier (1984), at the heart of our material relationship with nature, there is an underlying non-material bond that unites the three key functions of knowledge to simultaneously represent, organize and legitimize our social relations with nature. Thus, together with defining a space for economic reproduction and projecting principles of social relations, terrestrial and marine territories can also be the locus of representations of the mythological imagination of these traditional societies. The intimate relation of these people with their surroundings, and their greater dependency on the natural world when compared to urban-industrial societies', result in the cycles of nature (the arrival of schools of fish and the abundance of crops) being associated with mythical and religious explanations.

- Participatory approach and empowerment: Ethnoconservation applied to protected areas establishment and management, requires a continuous and strong participation in the decision of what type of protected area is going to be established, which is the role of local associations in the decision of making process, in monitoring and evaluation. 
Empowerment is primarily related to the control of the territory to be transformed into protected area and the recognition by the authorities of the social and cultural rights of the traditional peoples and communities involved. (Pimbert \& Pretty 1997).

\section{The necessary dialogue between natural sciences, social sciences and ethnoscience}

The recent importance given to sustainable use reserves in Brazil, in which local communities play a central role, made evident that «Conservation is a social (and epistemological) practice» involving the protection and sustainable use of natural resources (Larrère \& Larrère 1997; Toledo 2001). It requires an organic cooperation between social sciences, natural sciences and traditional knowledge. There are at least two questions concerning this cooperation. First, there are still some social scientists working in nature conservation because they consider it a feud of biologists and they do not want to be contaminated by geographic-biological determinism. Second, there is a difficulty in finding a (methodological) common ground to work together, given the various methodologies of natural and social sciences. As long as some biologists think that the central concept in nature conservation is wilderness from which human beings must be absent and that only pristine environments have to be protected, the space for collaboration is reduced. At the same time as long as some social scientists consider nature only as a social construction, the cooperation with natural scientists is doomed to fail.

The fact is, however, that some few social and natural scientists started cooperating in the planning and management of sustainable use of protected areas is a good starting point. Ethnoscience (ethnoecology, ethnobiology, ethnoichtyology, etc.) is often being used as a bridge between social and natural scientists.

Therefore, there is a need to improve cooperation among social sciences in order to understand conservation as a social practice that appeared in a given historical and political context of modernity. Some disciplines have been more involved in the conservation debate - especially history through environmental history, and environmental geography. There are few interactions between anthropology, sociology, and political ecology in the tropics. In some Southern countries, the crucial role of political ecology to understand conservation has almost disappeared, although it was important in the Seventies in countries such as Brazil (Diegues 2008).

Some concepts and approaches such as the "ecosystem approach » used by biologists were not built in order to integrate social and cultural dimensions. More recently, this approach became a kind of dogma as in some important international conventions, such as the Convention for Biological Diversity (CBD 2012) where it is recommended as the only possible approach to conservation and sustainable use of biodiversity. As far as conservation biology is concerned, even biologists (at least in Brazil) recognize that the methodology is unable to incorporate the social and cultural dimensions of conservation. Concepts such as landscape, co-evolutionary process, as results of interactions between society and nature are more appropriate to deal with the relationships between society and the environment.

31 An important contribution to incorporate ethnoecology into ethnoconservation was done by M. Balick and P. Cox (1996) when they propose that « a new and very important branch 
of ethnobotany might be termed 'ethnoconservation biology' the incorporation of indigenous conservation models into wildlands biology ».

\section{The Role of ethnoscience in Brazil}

Ethnoscience, in particular ethnobiology/ethnoecology, is one of the fastest growing area of research and knowledge in Brazil, attracting a large number of biologists interested not only in traditional knowledge and management, but also in the socio-cultural aspects of nature conservation. Although in many theses and papers, the social groups in which this knowledge is constructed are seldom analyzed, ethnoscience is contributing to a more socially/ecologically-oriented conservation.

In Brazil, the studies and research on traditional knowledge were initiated by anthropologists such as Baldus (1937), Levi-Strauss (1989), Berta Ribeiro (1986), Laure Emperaire (1978), Darrel Posey (1986). They were mostly based among Brazilian Indians.

From the eighties onwards, ethnoscience emerged as an important field of research, particularly in the domain of ethnobiology, ethnobotany, ethnoecology undertaken by researchers from the natural sciences. In 1986, Darcy Ribeiro coordinated an important reader called Summa Ethnologica Brasileira, and Berta Ribeiro organized the first volume ( Ethnobiology) with the contributions of authors such as Levi-Strauss, Robert Carneiro, Ghillean Prance and Darrel Posey, among others.

It is interesting to note that the increase of these studies coincided with the emergence of Indians and traditional communities as new social actors linked with the discussions on nature conservation as a reaction to the destruction of forests and loss of Indian languages and territories. Also in the beginning of the 1990s, the First International Symposium on Ethnobiology took place in Belem, with the contribution of national and international researchers as well as representatives from Traditional Peoples. The main contribution was that of the anthropologist-ecologist Darrel Posey who had already established a relationship between nature conservation, traditional knowledgemanagement and the need to protect traditional knowledge. This last issue was taken by the Convention on Biological Diversity, signed in Rio de Janeiro during the UN Conference on Environment and Development in 1992. During this Convention it was clearly stated that Governments should respect and protect traditional knowledge, and guarantee a fair benefits distribution to local communities when their knowledge is used for commercial purposes (article 8j). 
Photographie 1 : Building artificial habitats for fish along Paraty Coast - Rio de Janeiro

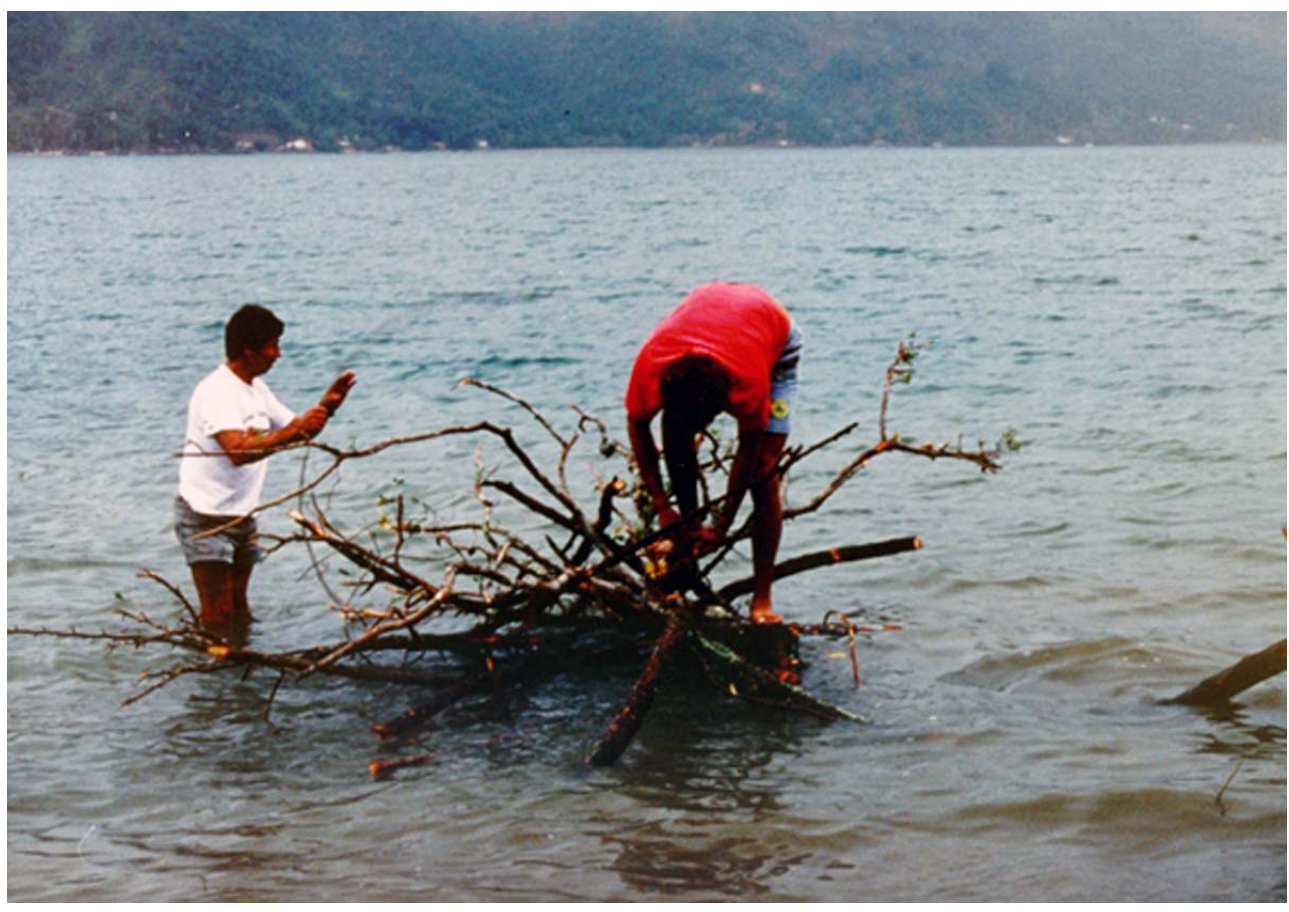

(C) DIEgUES

Photographie 2 : Building of traditional fisher's house in Maranhão coast

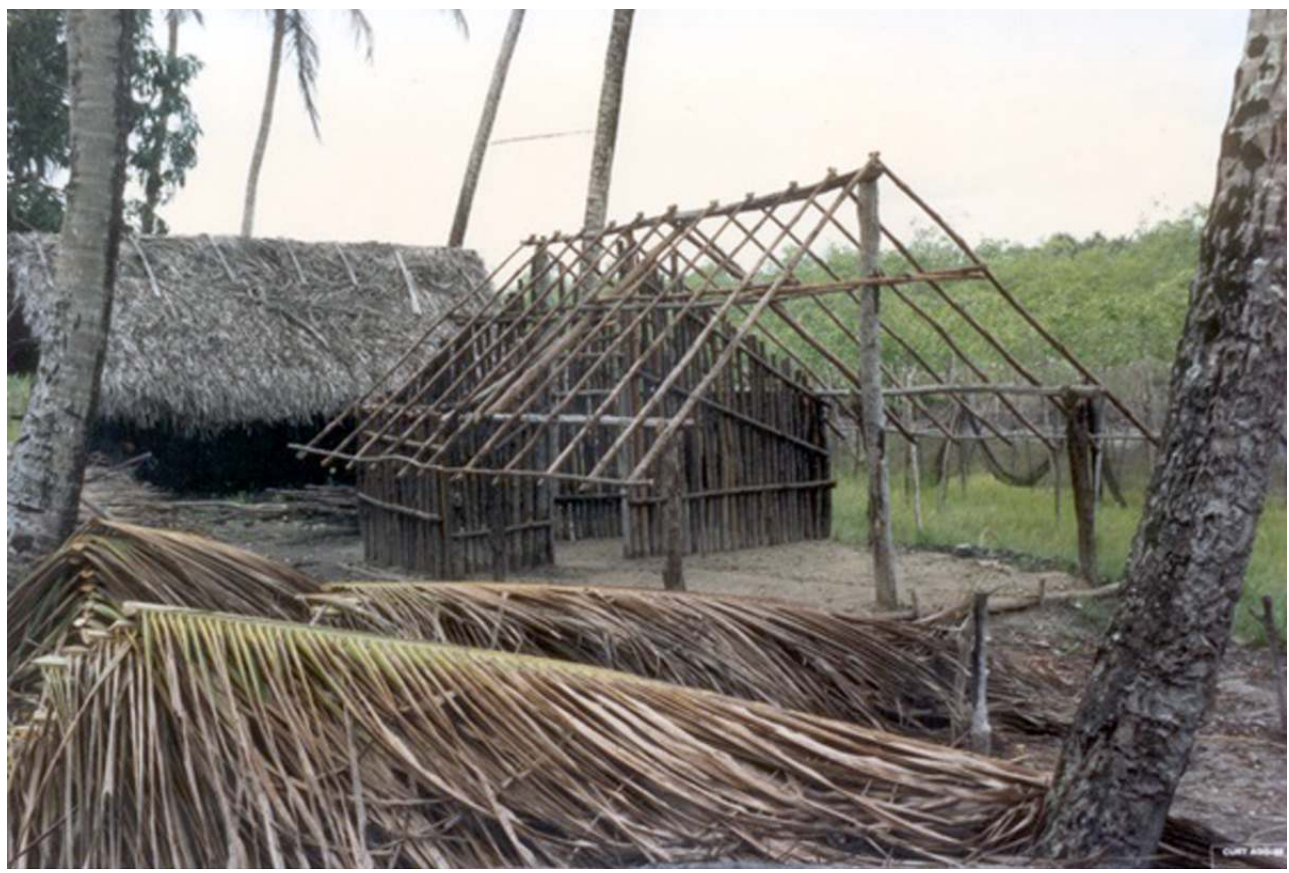

(C) DIEgUES 
Photographie 3 : Fisherman collecting mangrove leaves for medicine in Pernambuco coast

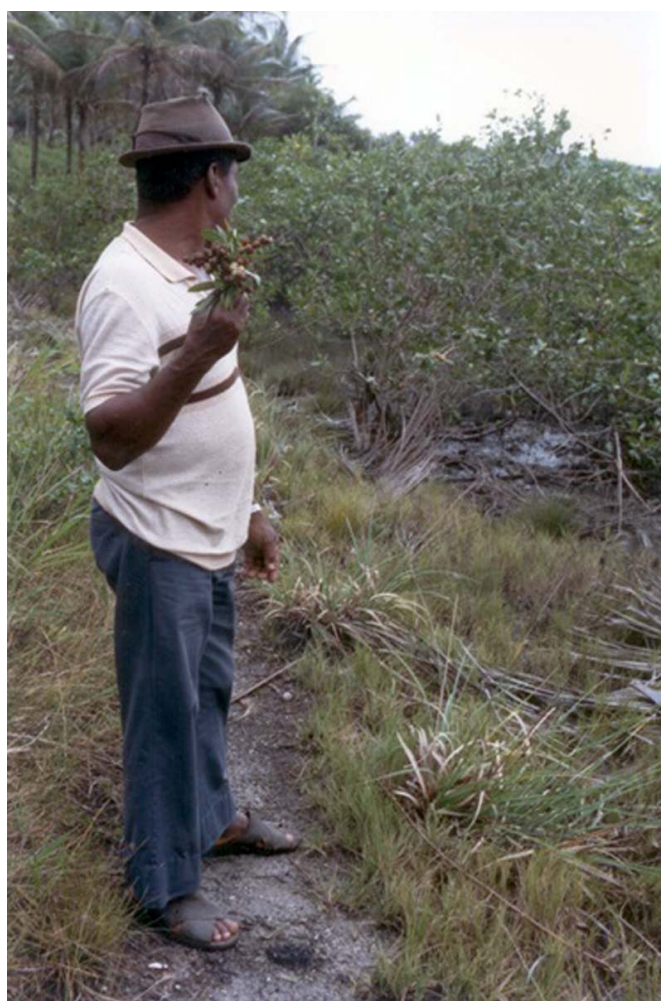

(C) DIEgUES

Photographie 4 : Fisherman collecting oyster in Mandira Extractive Reserve in Cananeia - São Paulo State

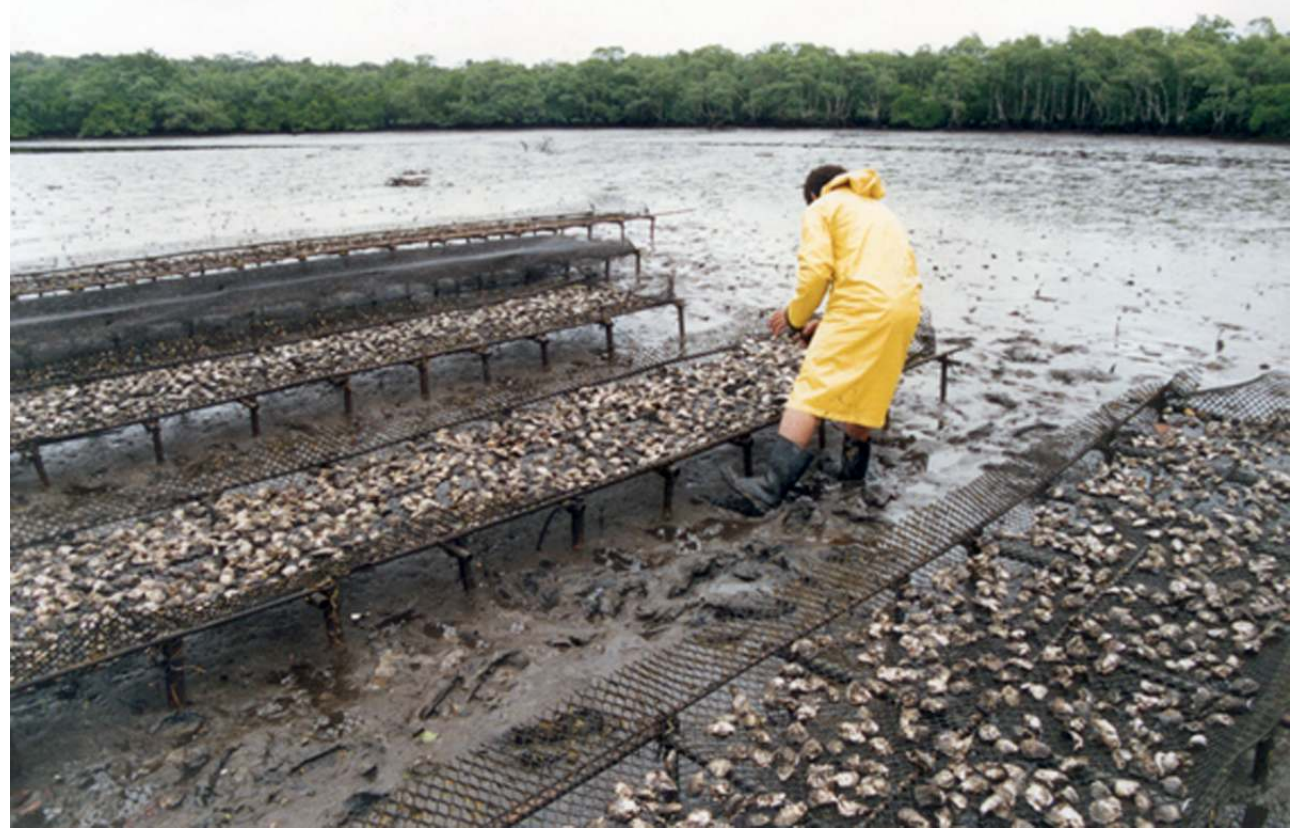

(C) DIEgUES 
Photographie 5 : Yemanjá, goddess of the sea for fishermen from Bahia

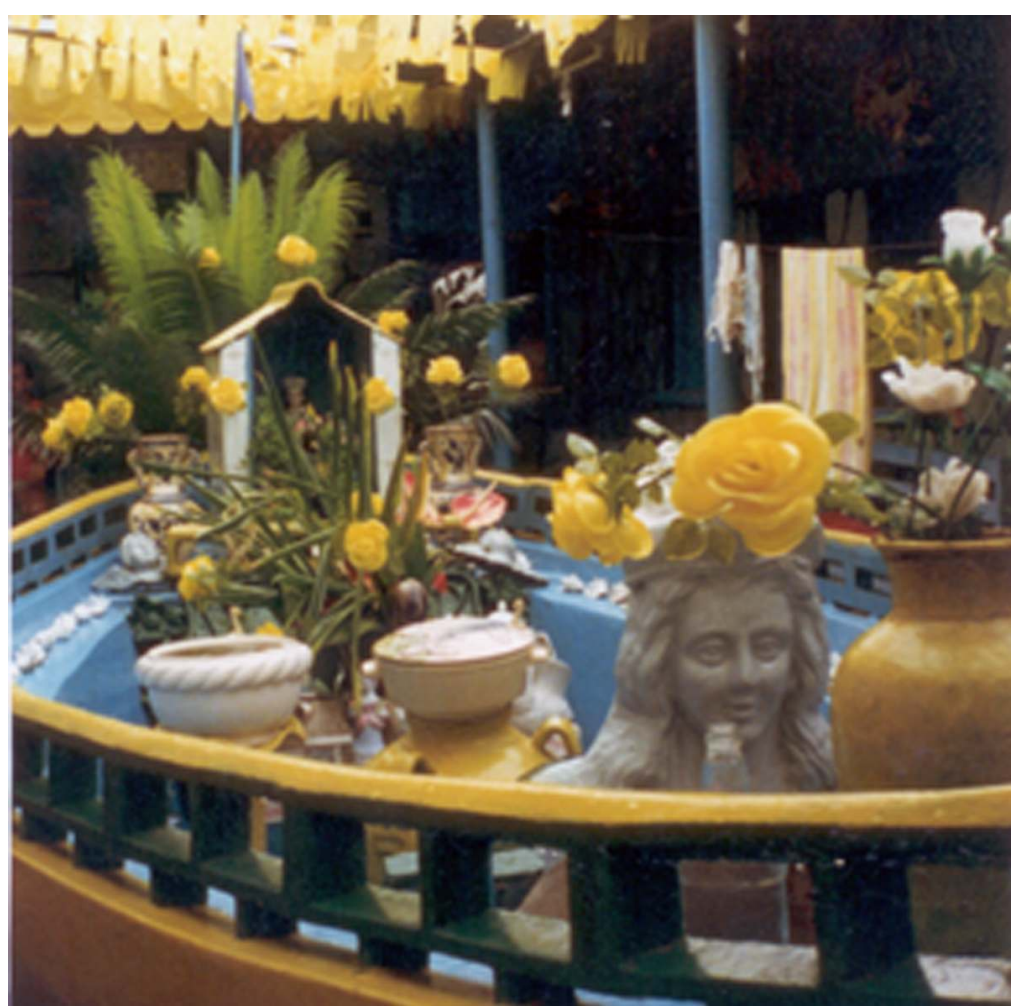

(C) DIEgUES ethnoecology, the Brazilian Society of Ethnobiology and Ethnoecology was created. Every two years, it organizes a national congress in addition to regional congresses. Although the majority of participants are from the world of natural sciences world, researchers from different social sciences and representatives from Traditional Peoples also participate. (http://www.etnobiologia.org/sbee/apresentacao/apresentacao.php).

rvey undertaken in 1990 (Diegues \& Arruda 2001) reveals that, until the 1980s, from 900 papers selected on traditional knowledge and management in Brazil, around $44 \%$ were about Indians and were written in the majority by anthropologists. From the 1990s onward, the situation has changed to almost $60 \%$ of the publications being on non-Indian peoples (traditional communities resulting from the mixing of European, Indians and Black Africans), covering different disciplines of Ethnoscience. Among the most studied traditional communities were the Quilombolas (77\%), Amazonian caboclos (67\%), artisanal fishers (61\%), caicaras fishers (60\%).

The increase in the academic production on ethnoscience from the 1990s onwards can be explained by the fact that many natural sciences students wanted to conduct field work among traditional communities (fishermen, peasants) and there was no discipline on human ecology in their Department of Biological Sciences. Ethnobiology and ethnoecology emerged as a bridge between natural and social issues. At the same time, disciplines on these issues started to become available in some university institutions (Universidade Estadual da Bahia, Universidade Federal de São Carlos (SP), Universidade Federal de Santa Catarina). The conferences organized by the Brazilian Society for 
Ethnobiology and Ethnoecology also offered a floor for research presentations for a growing number of students.

It can be noticed that the interest for traditional knowledge and management is related to a growing concern on the fate of indigenous peoples and traditional communities threatened by the occupation of their territories by the expansion of agro-business, dams, harbours during the last two decades. The loss of Indian languages and peoples all around Brazil (not only in the Amazon) is closely related to the destruction of forests and waters from which they depend to live. In this connection, the loss of traditional knowledge is a concern also for those who study this issue.

International Conventions, such as the ILO 169 Convention $^{1}$, the activities of the UN Forum of Indigenous Peoples, the Convention on Biological Diversity, calling Government and Society to respect traditional peoples rights and knowledge have stimulated the interest in Brazil for the study on traditional knowledge. In several Government documents, it is stated that traditional knowledge should be used together with science in the fields, such as protect areas planning and implementation, research and sustainable use of natural resources (fisheries, forest) but, in practice, this seldom occurs. Among the reasons that hinder the use of traditional knowledge in the above activities, there are the limited number of people trained in ethnoecology-ethnobiology, the limited knowledge on the social context in which the traditional knowledge is produced (Bahuchet et al. 2000), the limited number of social scientists working in these fields, the resistance of some officials in recognizing the positive role of traditional knowledge, the political weakness of traditional peoples, inter alia.

\section{Conclusions}

41 Ethnoconservation is a new approach to nature conservation under construction in different tropical countries, based on interdisciplinary cooperation and on experiences of the Traditional Peoples through their knowledge in nature management practices. Ethnoecology and ethnobology, as welle as other branches of ethnoscience, have an important role in the process as a bridge between social and natural sciences. It takes also the contribution of Political Ecology, as ultimately nature conservation is a controversial one, in a scenery where various social forces and classes have different and often conflictive views (nature conservation versus agrobusiness, dam constructions, tourism, etc.). Traditional Peoples constitute a new player in this hard game, politically weak and their strength depending on different kind of alliances both national and international. Many of them are under severe threats from hard development projects as well as from ill-conceived conservation initiatives that lead to territorial expropriation, loss of identity, language, culture and territories.

It is also becoming clear that new approaches to conservation are needed, taking into consideration the complex relationships between societies and environments in Brazil as well as in other tropical countries based not only in protected areas. The possibility of establishing a protected area of any kind is reaching its limits in terms of land and conflicts. The simplistic and still dominant, hegemonic approach of national parks as conservation fortress is not performing well, in spite (or because) of authoritarian practices, ideological views of wilderness, of lack of interdisciplinarity (including ethnoecology and traditional knowledge) in spite of funds and political influence of big international NGOs. 
New social and ecological practices are required and have to be built based on an interdisciplinary approach that also take into consideration local/traditional knowledge and social and democratic participation. In some southern countries such as India, Brazil, Mexico and many others, new approaches and experiences in nature conservation that take into consideration biological as well as cultural diversity are being constructed. Some people call this new approach: ethno-conservation.

\section{BIBLIOGRAPHY}

Alcorn J. 1993 - Indigenous peoples and Conservation. Conservation Biology 7 : 424-426.

Bahuchet S., Grenand F., Grenand P. \& Maret P. de 2000 - Forêts des tropiques, forêts anthropiques, sociodiveristé, biodiversité: un guide pratique. Bruxelles : APFT - ULB, $132 \mathrm{p}$.

Baldus H. 1937 - Ensaios de etnologia brasileira. São Paulo, Compania Editora Nacional.

Balée W. 1993 - Footprints of the forest: Ka'apor ethnobotany. The historical of plant utilization by an Amazonian people. NewYork, Columbia University Press, 416 p.

Ballick M \& Cox P. 1996 - Plants, people and culture. The science of Ethnobotany. New York, Scientific American Library, 228 p.

Berkes F. 1999 - Sacred Ecology: traditional, ecological, knowledge and resource management. Philadelphia and London, Taylor \& Francis, 209 p.

Chapin M. 2004 - A challenge to conservationists. World Watch Magazine 17 (6) : 17-31.

Chimere-Diaw M. 2008 - Scales in Conservation-another clash of civilization. In Diegues A. Etnoconservação, Hucitec, Center for International Forestry Research-Cifor.

Diegues A. 1998 - Recycled rain Forest myths. Terra Nova, Nature and Culture (The world and the wild), 3 (3).

Diegues A. 1999 - The modern myth of untamed nature. São Paulo, USP/Nupaub.

Diegues A. (Org.) 2008 - A ecologia política das grandes ONGs transnacionais conservacionistas. São Paulo, Nupaub-USP, 193 p.

Diegues A. \& Arruda R. 2001 - Saberes tradicionais e biodiversidade. Brasília, MMA, 176 p.

Diegues A. and B. \& Cordell J. 2001 - Traditional Fisheries knowledge and social appropriation of marine environment. In Brazil. Paper presented at Maré Conference, Amsterdam, aug/sept.

Dowie M.C. 2006 - The conservation refugees. Available online at oriononline.org.

Emperaire L. 1978 - Relevé ethnobotanique dans la caatinga du sud-est du Piauí. Dissertação de Mestrado, Paris, Universidade de Paris 6.

Gadgil B., Berkes F. \& Folke C. 1993 - Indigenous knowledge for Biodiversity Conservation. Ambio $22: 151-156$.

Godelier M. 1984 - L'idéel et le matériel : pensée, économies et sociétés. Paris, Fayard, 350 p.

Gomez-Pompa A. \& Kaus A. 1992 - Taming the wilderness myth. Bioscience 42 (4) : 271-279. 
Guha R. 1997 - The authoritarian biologist and the arrogance of anti-humanism. Wildlife conservation in the Third World. The ecologist 27 (1) : 14-19.

Larrère C. \& Larrère R. 1997 - Du bon usage de la nature. Pour une philosophie de l'environnement. Paris, Aubier : 355 p. (Alto).

Levi-Strauss C. 1989 - O pensamento selvagem. Papyrus, Campinas.

Pimbert M. \& Pretty J. 1997 - Parks, People into protected área management. In Ghimire K. \& Pimbert M. Social change and conservation:environmental politics and impacts of national parks and protected areas. Earthcan Publishing.

Posey D.A. 1986 - Manejo da floresta secundaria, capoeiras, campos e cerrados (Kayapo). In Ribeiro B. Suma Etnologica Brasileira, vol 1 : Etnobiologia. Petrópolis, FINEP/Vozes : 173-188.

Posey D.A. 1992 - Interpreting and applying reality of Indigenous Concepts: what is necessary to learn from the natives? In Redford K.I.H. \& Paddoch C. (Ed.). Conservation of Neotropical Forests: working from traditional resource use. New York, Columbia University Press : 21-34.

Ribeiro D. (Ed.) 1986 - Suma etnológica brasileira. vol 1 : Etnobiologia. Petrópolis, FINEP/Vozes.

Ribeiro B. 1986 - Etnobiologia (Ed.). In Ribeiro D. (Ed.) Suma etnológica brasileira. Petrópolis. FINEP/Vozes.

Ruddle K. 2000 - Systems of knowledge: dialogue, relationships and process. In Begossi A. \& Hens L. Environment, development and sustainability 2 (3-4) : 277-304.

Sarkar S. 1998 - Restoring Wilderness or reclaiming forests. Terra Nova, Nature and Culture 3 (3) : 35-51.

Toledo V. M. 1992 - What is ethnoecology? Origins, scope and implications of a rising discipline. Etnoecológica, 1 (1) : 5-21.

Toledo V. M. 2001 - Indigenous peoples and biodiversity. In Levin S. et al. Encyclopedia of Biodiversity. Academic Press : 330-340.

\section{NOTES}

1. C169 Indigenous and Tribal Peoples Convention. 1989. International Labour Organization.

\section{ABSTRACTS}

This paper aims to describe the main features of a new approach in nature conservation in the Tropics and to analyse the important role of ethnoscience in this process, taking Brazil as a case study.

It begins with a critique of the hegemonic model for nature conservation in which traditional communities living in the areas transformed into non-use protected areas have been displaced or too severely hindered to continue with their traditional way of life based on small-scale agriculture, fishing, forest harvesting and hunting. The role of big international conservation NGOs in spreading this hegemonic approach in developing countries is also analysed. 
This model is being set-up in many tropical countries. It consists in recognizing the rights of traditional communities to their territories, using traditional knowledge, encouraging people to participate and ensuring the cooperation between natural and social sciences in the process of nature management.

Cet article a pour but de décrire les principales caractéristiques d'une nouvelle approche de la conservation de la nature dans les régions tropicales et d'analyser le rôle important de l'ethnoscience dans ce processus, en prenant le Brésil comme étude de cas.

D'abord il présente une critique du modèle hégémonique de conservation de la nature qui a déplacé les communautés traditionnelles vivant dans ces zones protégées ou a sévèrement entravé leur mode de vie traditionnel fondé sur l'agriculture, la pêche la cueillette et la chasse. Le rôle des grandes ONG dans la propagation de cette approche dominante dans les pays en développement est également analysé.

La reconnaissance des droits territoriaux des communautés traditionnelles, l'utilisation de leur savoir traditionnel, la participation des populations et une coopération entre les sciences naturelles et sociales dans les méthodes de gestion de la nature sont les principales caractéristiques de ce nouveau modèle mis en œuvre dans de nombreux pays tropicaux.

\section{INDEX}

Keywords: ethnoscience, ethnoconservation, traditional knowledge, traditional communities, Brazil, protected areas, biological diversity, cultural diversity, traditional rights of communities Mots-clés: ethnoscience, ethnoconservation, savoir traditionnel, communautés traditionnelles, aires protégées, diversité biologique, diversité culturelle, droits traditionnels des communautés Geographical index: Brésil

\section{AUTHOR}

\section{ANTONIO CARLOS DIEGUES}

Anthropologist, University of São Paulo, Brazil 